Tamara Apostolović ${ }^{1}$, Jelena Tričković ${ }^{1 \star}$, Aleksandra Šućurović ${ }^{2}$, Marijana Kragulj Isakovski ${ }^{1}$, Snežana Maletić ${ }^{1}$, Srđan Rončević ${ }^{1}$, Božo Dalmacija ${ }^{1}$

${ }^{1}$ University of Novi Sad, Faculty of Sciences, Department for Chemistry, Biochemistry and Environmental Protection, Novi Sad, Serbia, ${ }^{2}$ Technical College of Applied Sciences in Zrenjanin, Zrenjanin, Serbia
Scientific paper

ISSN 0351-9465, E-ISSN 2466-2585 UDC:620.198.7(n) doi: $10.5937 / Z a s M a t 1802216$ A

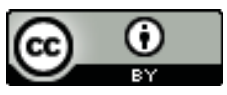

Zastita Materijala 59 (2) 216 - 225 (2018)

\title{
Adsorption kinetics of divalent metals on amino-functionalized carbon nanomaterial
}

\begin{abstract}
The subject of this study was to investigate the adsorption behavior of selected divalent metals (Cu (II), Cd (II), Pb (II)) on amino-functionalized multiwalled carbon nanotubes, MWCNT-NH $\mathrm{H}_{2}$ at four selected $\mathrm{pH}$ values $(3 ; 4.5,6,11)$, in order to estimate the possibility of using $M W C N T-\mathrm{NH}_{2}$ to remove ion metal from aqueous solutions at relatively low concentrations (0.01-0.1 mg L $\mathrm{L}^{-1}$ ). The focus of the study was to determine the adsorption mechanism at the experimental conditions. The adsorption of divalent metal ions on MWCNT-NH $\mathrm{H}_{2}$ was best described by the pseudo-second order kinetics model, which indicates that adsorption can be attributed to the chemical interactions between the adsorbates and the binding groups on the surface of the adsorbent. Modeling the adsorption rate by the Weber-Morris diffusion model indicated that intra-particle diffusion, although a slower step than external diffusion, is not the only limiting step in the adsorption process, and that the interaction of the investigated ions with the binding sites on the adsorbent surface also control the adsorption rate. Assessment of the impact of $\mathrm{pH}$ on the adsorption rate has shown that the $\mathrm{pH}$ value, in the investigated range, has the highest effect on the adsorption efficiency of $\mathrm{Cu}$ (II) and the lowest for the removal of Cd (II).
\end{abstract}

Key words: nanomaterials, divalent metals, adsorption, kinetics.

\section{INTRODUCTION}

The presence of heavy metals in aquatic environments has attracted the attention of researchers in the last few decades, due to their high toxicity, prevalence and persistence [1]. Discharge of untreated or insufficiently treated municipal and industrial wastewaters has led to a rise in the concentration of heavy metals in rivers [2]. The behaviour of metals in natural waters depends on the chemical composition of the water [3]. Under aerobic conditions, free metal ions are present at lower $\mathrm{pH}$ values, whereas, with increasing $\mathrm{pH}$ precipitation of metals in the form of carbonates, oxides and hydroxides begins to occur. Divalent metal ions are hydrolyzed at the $\mathrm{pH}$ range of natural waters, forming polynuclear complexes, which can, with time, condense into insoluble oxides or hydroxides [4].

Corresponding author: Jelena Tričković

E-mail: jelena.trickovic@dh.uns.ac.rs

Paper received: 19. 02. 2018.

Paper accepted: 25. 04. 2018.

Paper is available on the website: www.idk.org.rs/journal
With the invention of carbon nanotubes (CNTs), due to their exceptional, easily adaptable mechanical and chemical properties, a large specific surface area and a porous and hollow structure, began their application in various fields of science and technology $[5,6]$. One of the areas of application are water purification technologies [7]. Pristine CNTs have a very low affinity for metals adsorption $[8,9,10]$, as well as a low dispersivity in aqueous solutions, thus requiring modification in order to increase their efficacy to remove metal ions [11]. The most common modification involves the oxidation of CNTs by concentrated acids, which increases the content of oxygen functional groups $(-\mathrm{OH},-\mathrm{COOH},-\mathrm{C}=\mathrm{O}$, etc. $)$ at the adsorbent surface. This, on the one hand, increases their affinity for heavy metal binding [12] due to the charge transfer between the functional groups and the metal cations [13], and on the other hand, facilitates dispersion due to the increase in polarity of the CNTs, which further facilitates the manipulation and practical application of these materials in water treatments. In addition to CNT oxidation, the introduction of amino group $\left(-\mathrm{NH}_{2}\right)$ has also been found very interesting, because it enables bonding with metal ions [5] and functional 
groups of other compounds of interest such as biomolecules [14] and polymers [15].

The degree of ionization and the form in which the observed adsorbate appears, as well as the adsorbent surface charge, depend on the $\mathrm{pH}$ of the water solution, and their mutual relations determine the possibility of interaction formation and the degree of adsorption. Furthermore, the change in $\mathrm{pH}$ value affects the complexation reaction and the speciation of metal ions, and therefore $\mathrm{pH}$ value represents one of the most important factors affecting the capacity of CNTs for metal ions adsorption $[12,16,17]$.

The objective of this paper was to investigate the possibility of amino-functionalized multiwalled carbon nanotubes (MWCNT-NH ) application in removing metal ions from aqueous solutions in the region of relatively low concentrations (ppb) at four different $\mathrm{pH}$ values ranging from 3 to 11 .

\section{EXPERIMENTAL}

\subsection{Synthesis and characterization of nanomaterials}

Multiwalled carbon nanotubes were synthesized in the catalytic chemical vapor deposition process (CCVD) using acetylene as a source of carbon and in the presence of sol-gel Co-Fe silica catalyst [18]. The modification of MWCNTs by amino groups was done according to the method of Wang et al. [19]. In a typical synthesis, $20 \mathrm{ml}$ of a 10:9 volume ratio mixture of $\mathrm{cc} . \mathrm{H}_{2} \mathrm{SO}_{4}$ and cc. $\mathrm{HNO}_{3}$ was added in drops to $500 \mathrm{mg}$ of pristine MWCNTs. The mixture was stirred for 90 minutes at $60{ }^{\circ} \mathrm{C}$, and then cooled to room temperature by adding $600 \mathrm{ml}$ of water to terminate the reaction. The resulting MWCNTs- $\mathrm{NO}_{2}$ material was filtered, washed until $\mathrm{pH} 7$ and dried. In the next step, MWCNTs- $\mathrm{NO}_{2}$ material was reduced. First, $1 \mathrm{~g}$ of iron powder, $2 \mathrm{ml}$ of acetic acid and $50 \mathrm{ml}$ of distilled water were mixed and refluxed for $10 \mathrm{~min}$ to activate iron into ferrous acetate. Then, $200 \mathrm{mg}$ of MWCNTs- $\mathrm{NO}_{2}$ were added to reaction system and refluxed for 1 hour. At the end of the reaction, remaining iron powder was removed with magnet and the amino-functionalized MWCNTs were filtered, washed with $0,01 \mathrm{M} \mathrm{HCl}$ and distilled water and dried.

The point of zero charge $\left(\mathrm{pH}_{\mathrm{PzC}}\right)$ was determined by the mass titration method [20,21]. Specific surface area (SSA) and pore volume (PV) of MWCNT-NH $\mathrm{N}_{2}$ were measured by nitrogen adsorption/desorption at $77 \mathrm{~K}$ using the Autosorb iQ Surface Area Analyzer (Quantochrome Instruments, USA). SSA was calculated using the BET method (Brunauer-Emmett-Teller). The mezopore volume was determined by applying the desorption isotherm of the $\mathrm{BJH}$ (Barrett-Joyner-
Halenda) model. The micropore volume was calculated using the t-test method. The characterization of MWCNT- $\mathrm{NH}_{2}$ surface functional groups was performed using a Nexus 670 infrared spectrophotometer (Thermo Nicolet, USA) [22].

\subsection{Adsorption kinetics of divalent metals on MWCNT-NH}

Adsorption kinetics of copper, lead and cadmium ions on MWCNT- $\mathrm{NH}_{2}$ were tested by batch experiments at room temperature $\left(20 \pm 2{ }^{\circ} \mathrm{C}\right)$ and at different $\mathrm{pH}$ values $(\mathrm{pH} \mathrm{3,4.5,6}$ and 11). The procedure was as follows: a certain mass of MWCNT- $\mathrm{NH}_{2}$ was measured in glass vials or Erlenmeyer flasks. Then, a certain volume of the background solution $\left(0.01 \mathrm{M} \mathrm{CaCl}_{2}\right.$ in deionized water) was added, in which the $\mathrm{pH}$ value was previously adjusted by $70 \% \mathrm{HNO}_{3}$ or $1 \mathrm{M} \mathrm{NaOH}$. The mass ratio of the adsorbent and the background solution was adjusted so that the adsorption of the tested metals ranged from $10 \%$ to $90 \%$. To enhance dispersion of the adsorbent, the prepared suspensions were placed in an ultrasonic bath for $30 \mathrm{~min}$. A specific volume of heavy metal working solutions (100 $\mathrm{mg} / \mathrm{L})$, was added to each vial or Erlenmeyer flask, in order to obtain initial metal ion concentrations in the range of $0.1-1$ $\mathrm{mg} / \mathrm{L}$. Vials, or Erlenmeyer flasks, were subjected to continuous shaking for $2,10,30,45,60,240$, $1440,2880,4320$ and $5760 \mathrm{~min}$. After the appropriate time period, suspensions were filtered through a membrane filter $(0.22 \mu \mathrm{m})$ and acidified with 2-3 drops cc. $\mathrm{HNO}_{3}$. Heavy metal concentrations in the filtrate were determined by atomic absorption spectroscopy (AAS) (Perkin Elmer AAnalyst 700) according to EPA 7000b [23] and EPA 7010 [24] methods. Work solutions of the selected metals were prepared by diluting standard solutions (1000 mg/L, Merck) in deionized water.

\subsection{Data analysis}

In order to investigate the adsorption kinetics four kinetic models were applied: pseudo-first order model, pseudo-second order model, Elovich model and intra-particle diffusion model. Lagergren's model of the pseudo-first order is expressed by the equation (Eq. 1):

$$
\ln \left(q_{e}-q_{t}\right)=\ln q_{e}-k_{1} t
$$

where $q_{e}$ and $q_{t}(\mathrm{mg} / \mathrm{g})$ are the adsorption capacities at equilibrium and at time $t(\mathrm{~min})$, and $k_{1}$ $\left(\mathrm{min}^{-1}\right)$ is the pseudo-first order adsorption rate coefficient. Discrepancy between the experimental and theoretically obtained $q_{e}$ values indicates that the applied pseudo-first order model is not valid and that the adsorption process is governed by a much more complex mechanism [25]. 
The pseudo-second order model is expressed by the following equation (Eq. 2) [26]:

$$
\frac{t}{q_{t}}=\frac{1}{k_{2} q_{e}^{2}}+\frac{1}{q_{e}} t
$$

where $k_{2}(\mathrm{~g} / \mathrm{mg} / \mathrm{min})$ is the pseudo-second order adsorption rate coefficient. The initial adsorption rate, $h(\mathrm{mg} / \mathrm{g} / \mathrm{min})$ can be calculated using the equation (Eq. 3):

$$
h=k_{2} q_{e}^{2}
$$

The Elovich equation assumes that the surfaces of solid adsorbents are energetically heterogeneous, and that at low surface coverage, neither the desorption process, nor the interaction between the adsorbed species can significantly affect the kinetics of the adsorption process [25]. The Elovich model is expressed by the following equation (Eq. 4):

$$
q_{t}=\beta \ln (\alpha \beta)+\beta \ln t
$$

where $\alpha(\mathrm{mg} / \mathrm{g} / \mathrm{min})$ is the initial adsorption rate, and $\beta(\mathrm{g} / \mathrm{mg})$ is the desorption coefficient, which depends on the degree of coverage of the adsorbent surface and the activation energy of the chemisorption [27].

Modelling the adsorption kinetics of processes involving adsorbents with porous structure requires the consideration of the intra-particle diffusion of adsorbates. A simple model for determining the intra-particle diffusion rate constant is given by the equation (Eq. 5):

$$
q_{t}=k_{i} t^{0,5}+C
$$

where $k_{i}\left(\mathrm{mg} / \mathrm{g} / \mathrm{min}^{0.5}\right)$ is the intra-particle diffusion rate constant, and $C(\mathrm{mg} / \mathrm{g})$ is the intercept which can indicate the thickness of the boundary layer.

Based on the experimental data, $q_{t}, t / q_{t}$, Int and $\ln \left(q_{e}-q_{t}\right)$ were calculated, which were then used to construct the corresponding time dependences [25]. The obtained values for the slopes and intercepts of these time dependences were used to calculate the corresponding constants of the mentioned models.

\section{RESULTS AND DISCUSSION}

\subsection{Characterization of nanomaterials}

The $\mathrm{pH}$ value of the aqueous suspension of the adsorbent on which the sum of positive charges is in balance with the sum of negative charges on the surface of the adsorbent, ie. where $\Delta \mathrm{pH}=0$, represents the point of zero charge. The point of zero charge for the examined adsorbent MWCNT$\mathrm{NH}_{2}$ was 6.4. This result is within the range of values for CNTs that can be found in the literature $[28,29,30,31,32]$. Based on the results, an increase in the adsorption capacity of MWCNT- $\mathrm{NH}_{2}$ for the studied divalent metals should be expected as the $\mathrm{pH}$ value of the solution increases, due to the surface charge changing from positive to negative.

Further characterization of MWCNT-NH included the determination of SSA, as well as PV, which amounted to $180 \mathrm{~m}^{2} / \mathrm{g}$ and $1.31 \mathrm{~cm}^{3} / \mathrm{g}$, respectively. The t-test used to examine micropore volumes showed that the investigated adsorbent does not contain micropores. According to the mean pore diameter (14.64 nm), MWCNT-NH ${ }_{2}$ can be classified as a mesoporous material.

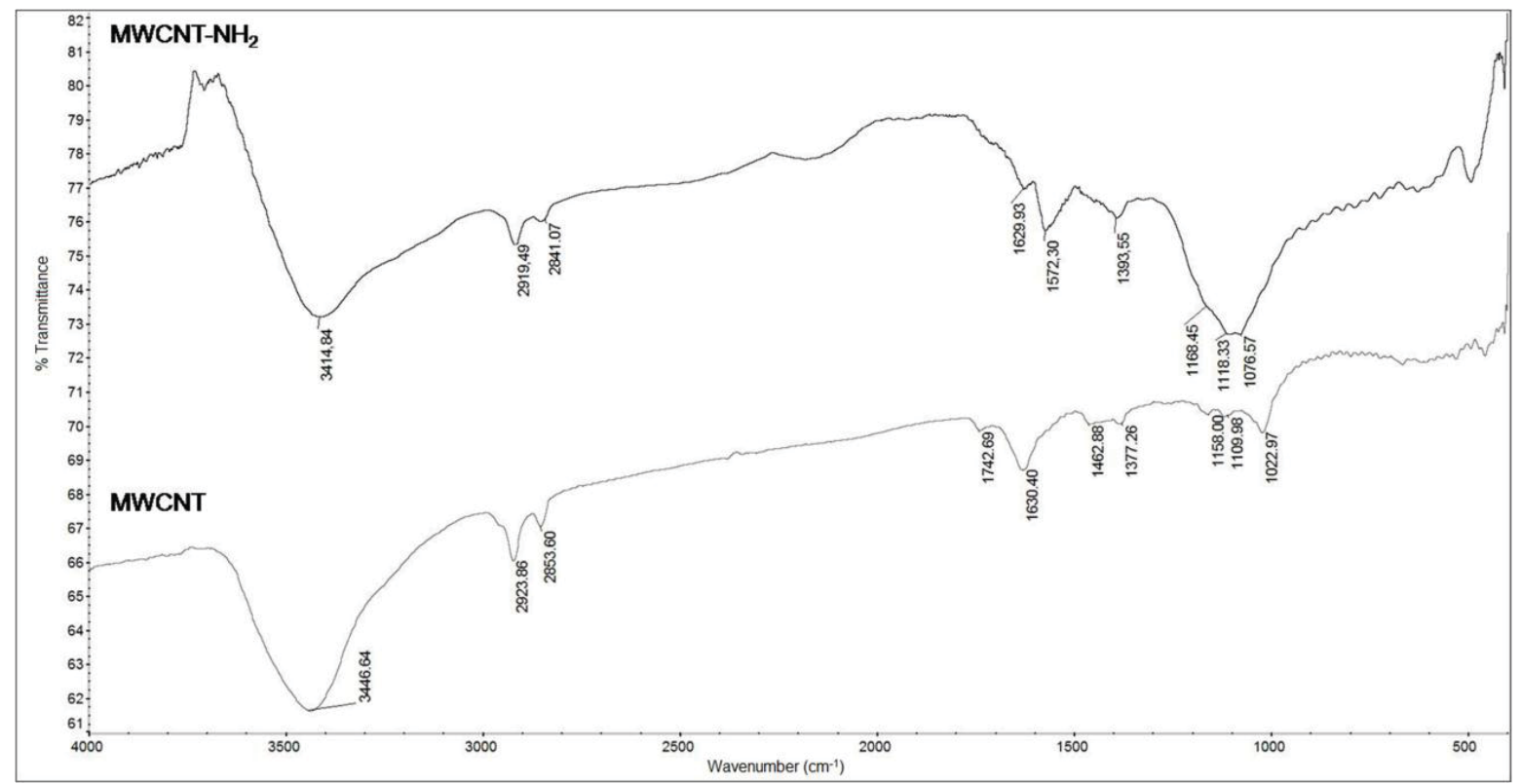

Figure 1. The FTIR spectra of pristine MWCNT and MWCNT-NH Slika 1. FTIR spektar nefunkcionalizovanih MWCNT i MWCNT-NH ${ }_{2}$ 
For the characterization of the surface functional groups on MWCNT-NH $\mathrm{N}_{2}$, FTIR spectra of pristine MWCNT and MWCNT-NH${ }_{2}$ were recorded (Fig. 1).

The FTIR spectra of pristine MWCNT showed bands at 1630, 2924 and $3447 \mathrm{~cm}^{-1}$ that may originate from stretching vibrations of $\mathrm{C}=\mathrm{C}$ aromatic bonds, stretching of the $\mathrm{C}-\mathrm{H}$ bonds and valent vibration of the $-\mathrm{OH}$ group originating from the moisture adsorbed on the sample or on $\mathrm{KBr}$, respectively [33]. MWCNTs- $\mathrm{NH}_{2}$ showed a number of bands that may originate from the functional groups of the primary amines. The band at $1630 \mathrm{~cm}^{-1}$ may originate from the bending vibrations of the $\mathrm{N}-\mathrm{H}$ bond, but could also be caused by vibrations of $\mathrm{C}=\mathrm{O}$ amidic groups on the CNT surfaces. In comparison to the pristine MWCNT, MWCNT-NH $\mathrm{N}_{2}$ showed a new band at $1572 \mathrm{~cm}^{-1}$ that may be caused by $\mathrm{N}-\mathrm{H}$ inplane streching, but also by vibration of carbon skeleton. The bands at $1076-1168 \mathrm{~cm}^{-1}$ correspond to C-N bond stretching, and the bands at $900 \mathrm{~cm}^{-1}$ and $857 \mathrm{~cm}^{-1}$ may be caused by out-of-plane $\mathrm{NH}_{2}$ bending. Additionally, the band at about $3414 \mathrm{~cm}^{-1}$ may be caused by the valent vibration of the $-\mathrm{OH}$ group, which can originate from the moisture adsorbed on the sample or on $\mathrm{KBr}$, but can also originate from the $\mathrm{N}-\mathrm{H}$ stretching vibration that should be in the same position [33,34]. Furthermore, bands around $2919-2941 \mathrm{~cm}^{-1}$ may originate from the symmetric and asymmetric valent vibrations of $-\mathrm{CH}_{2}$ groups [33].

\subsection{Adsorption kinetics of divalent metals on MWCNT-NH}

Adsorption kinetics of the three selected divalent metals were investigated in order to determine the time needed to reach the adsorptiondesorption equilibrium and determine the adsorption mechanism. The experiments were performed at four $\mathrm{pH}$ values $(\mathrm{pH} 3, \mathrm{pH} 4.5, \mathrm{pH} 6$ and $\mathrm{pH} 11$ ), where the kinetics at $\mathrm{pH} 11$ were tested for lead only. Namely, at $\mathrm{pH} 11$ the behaviour of copper and cadmium in the investigated system was partly conditioned by precipitation in the form of hydroxides, therefore it was not possible to determine the contribution of the adsorption process in the overall removal of these metals at the given condition. The adsorption rate was monitored over $96 \mathrm{~h}$, and the results obtained for all investigated $\mathrm{pH}$ values were shown as the change of metal ion concentration at a given time relative to its initial concentration $\left(C_{t} / C_{0}\right)$ over time, $t$ (Fig. 2). A period of $48 \mathrm{~h}$ was sufficient to establish the adsorption equilibrium for the investigated metal ions at all tested $\mathrm{pH}$ values.
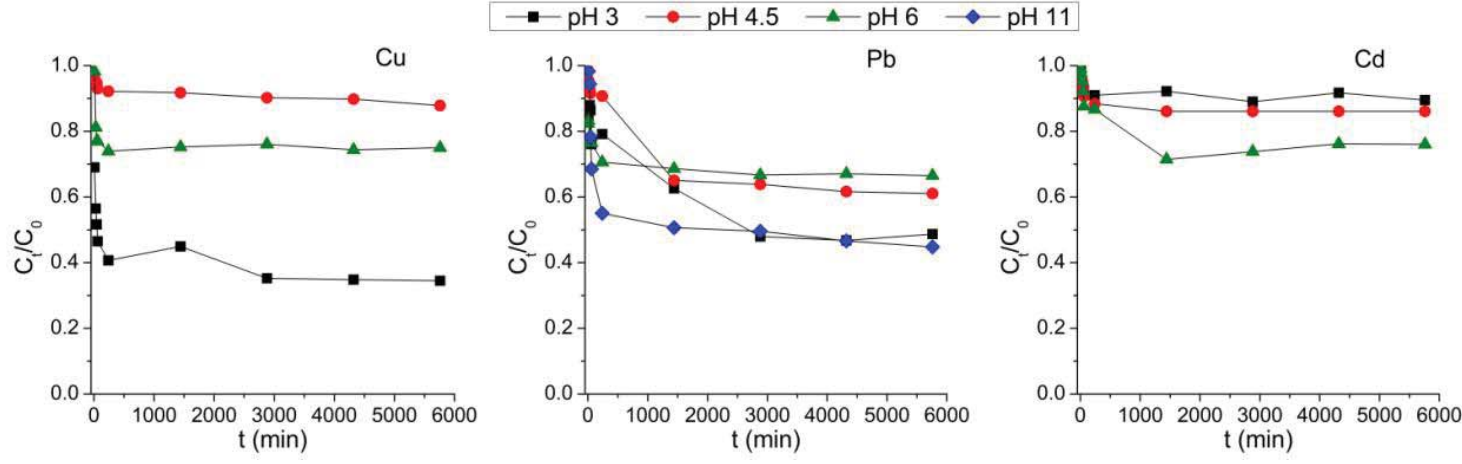

Figure 2. The removal rate of metal ions at different $\mathrm{pH}$ values

Slika 2. Brzina uklanjanja metalnih jona na različitim $\mathrm{pH}$ vrednostima

The obtained data indicate that the $\mathrm{pH}$ value in the investigated range has the greatest influence on the adsorption of copper, and least influences the removal of cadmium. The highest total reduction in the initial $\mathrm{Cu}$ (II) concentration was recorded at $\mathrm{pH} 3$ and the lowest at $\mathrm{pH} 4.5$. After 48 $\mathrm{h}$, the overall adsorption of $\mathrm{Cu}$ (II) ranged from $12 \%$ at $\mathrm{pH} 4.5$ to about $65 \%$ at $\mathrm{pH} 3$, out of which about $65-90 \%$ copper ions were removed during the initial period of $4 \mathrm{~h}$. At pH 6 the process was practically completed during the initial period with about 25\% copper ions removed, which was approximately the removal efficiency of the overall process after reaching equilibrium under the given condition. The highest $\mathrm{Pb}$ (II) adsorption was reached at $\mathrm{pH} 3$ and
$\mathrm{pH} 11$ after $48 \mathrm{~h}$, amounting about 50\% in both cases, out of which, during the initial period, almost twice the amount of $\mathrm{Pb}$ (II) ions (about 88\%) was removed under base conditions relative to the highly acidic environment (about 45\%). After 48 h, similar adsorption of lead ions was recorded at $\mathrm{pH}$ 4.5 and $\mathrm{pH} 6$ (38\% and 33\%, respectively), whereas, the amount of adsorbed lead ions in the initial period at $\mathrm{pH} 4.5$ was about three times lower than at $\mathrm{pH}$ 6. The adsorption rate of $\mathrm{Cd}$ (II) was generally low at all experimental $\mathrm{pH}$ values, ranging from between 9 and $13 \%$ in the initial period, to between 11 and 26\% after $48 \mathrm{~h}$ contact time. Out of the total amount of copper ions adsorbed, during the initial $4 \mathrm{~h}$, about $83 \%$ of 
copper were removed from the solution at $\mathrm{pH} 3$ and $\mathrm{pH} 4.5$, whereas at $\mathrm{pH} 6$ about $50 \%$ of copper were adsorbed.

\subsection{Modelling the adsorption kinetics of divalent metal ions on MWCNT-NH}

Adsorption at the liquid-solid interface can take place through several simultaneously occurring independent processes, such as external diffusion, intra-particle diffusion, chemical interactions, and others. In order to determine the adsorption mechanism, as well as the steps controlling the overall speed of the process, the data obtained by investigating the adsorption kinetics were modelled using three reaction kinetic models (Lagergren's pseudo-first order model, Ho and McKay's pseudosecond order model, and the Elovich model), as well as the Weber-Morris diffusion-adsorption model. The parameters obtained by applying these models to the experimental data are given in Table 1.

Table 1. Parameters of kinetic models for selected metals at different $\mathrm{pH}$ values

Tabela 1. Parametri kinetičkih modela za odabrane metale na različitim pH vrednostima

\begin{tabular}{|c|c|c|c|c|c|c|c|c|c|}
\hline \multirow[b]{3}{*}{ Metal } & \multirow[b]{3}{*}{$\mathrm{pH}$} & & & \multicolumn{3}{|c|}{ Kinetic model } & & & \\
\hline & & \multicolumn{2}{|c|}{ Pseudo-first order } & \multicolumn{3}{|c|}{ Pseudo-second order } & \multicolumn{3}{|c|}{ Elovich } \\
\hline & & $R^{2}$ & $\begin{array}{l}k_{1} \cdot 10^{-4} \\
\left(\min ^{-1}\right)\end{array}$ & $R^{2}$ & $\begin{array}{c}k_{2} \cdot 10^{-3} \\
\left(\mathrm{~g} \mathrm{mg}^{-1} \min ^{-1}\right)\end{array}$ & $\begin{array}{c}h \\
\left(\mathrm{mg} \mathrm{g}^{-1} \min ^{-1}\right)\end{array}$ & $R^{2}$ & $\begin{array}{c}\alpha \\
\left(\mathrm{mg} \mathrm{g}^{-1} \min ^{-1}\right)\end{array}$ & $\begin{array}{c}\beta \\
\left(m g^{-1} \mathrm{~g}\right)\end{array}$ \\
\hline $\mathrm{Cu}$ & & 0.871 & 6 & 0.998 & 7.72 & 0.0485 & 0.822 & 94.86 & 5.92 \\
\hline $\mathrm{Pb}$ & 3 & 0.719 & 7 & 0.986 & 1.32 & 0.0255 & 0.896 & 1.397 & 1.83 \\
\hline $\mathrm{Cd}$ & & 0.244 & 2 & 0.979 & 48.9 & 0.0044 & 0.541 & 0.265 & 44.5 \\
\hline $\mathrm{Cu}$ & & 0.852 & 6 & 0.999 & 1.23 & 0.0033 & 0.944 & 1.653 & 6.32 \\
\hline $\mathrm{Pb}$ & 4.5 & 0.978 & 1 & 0.987 & 2.41 & 0.2352 & 0.886 & 0.149 & 0.65 \\
\hline $\mathrm{Cd}$ & & 0.559 & 5 & 0.998 & 71.3 & 0.0092 & 0.889 & 0.109 & 24.9 \\
\hline $\mathrm{Cu}$ & & 0.118 & 3 & 0.997 & 23.2 & 0.0392 & 0.571 & 0.641 & 7.11 \\
\hline $\mathrm{Pb}$ & 6 & 0.118 & 3 & 0.997 & 23.2 & 0.0392 & 0.571 & 0.641 & 7.11 \\
\hline $\mathrm{Cd}$ & & 0.990 & 1 & 0.990 & 5.01 & 0.0490 & 0.888 & 0.137 & 2.00 \\
\hline $\mathrm{Cu}$ & & * & * & * & * & * & * & * & $*$ \\
\hline $\mathrm{Pb}$ & 11 & 0.487 & 6 & 0.994 & 5.12 & 0.1050 & 0.816 & 0.636 & 0.50 \\
\hline $\mathrm{Cd}$ & & * & * & * & * & * & * & * & * \\
\hline
\end{tabular}

* The values of these parameters are omitted, since the cause of the selected metals removal was not solely related to adsorption to MWCNT-NH , but also to other phenomena responsible for this process.

Table 2. Experimentally obtained and theoretically calculated $q_{e}$ values

Tabela 2. Eksperimentalno određene i teorijski izračunate $q_{e}$ vrednosti

\begin{tabular}{|c|c|c|c|c|}
\hline \multirow{3}{*}{ Metal } & \multirow{3}{*}{$\mathrm{pH}$} & $q_{e, \text { experimental }}$ & Pseudo-first order model & Pseudo-second order model \\
\hline & & $\left(\mathrm{mg} \mathrm{g}^{-1}\right)$ & $q_{e, \text { calculated }}$ & $q_{e, \text { calculated }}$ \\
\hline & & & $\left(\mathrm{mg} \mathrm{g}^{-1}\right)$ & $\left(\mathrm{mg} \mathrm{g}^{-1}\right)$ \\
\hline $\mathrm{Cu}$ & \multirow{3}{*}{3} & 2.51 & 2.36 & 2.49 \\
\hline $\mathrm{Pb}$ & & 4.43 & 3.05 & 4.52 \\
\hline $\mathrm{Cd}$ & & 0.30 & 0.68 & 0.23 \\
\hline $\mathrm{Cu}$ & \multirow{3}{*}{4.5} & 1.67 & 2.96 & 1.66 \\
\hline $\mathrm{Pb}$ & & 9.90 & 8.66 & 10.1 \\
\hline $\mathrm{Cd}$ & & 0.36 & 0.56 & 0.35 \\
\hline $\mathrm{Cu}$ & \multirow{3}{*}{6} & 1.30 & 1.61 & 1.19 \\
\hline $\mathrm{Pb}$ & & 2.30 & 2.40 & 2.25 \\
\hline $\mathrm{Cd}$ & & 3.13 & 2.33 & 3.31 \\
\hline $\mathrm{Cu}$ & \multirow{3}{*}{11} & * & * & * \\
\hline $\mathrm{Pb}$ & & 14.5 & 6.67 & 14.1 \\
\hline $\mathrm{Cd}$ & & * & * & * \\
\hline
\end{tabular}

* The values of these parameters are omitted, since the cause of the selected metals removal was not solely related to adsorption to MWCNT-NH , but also to other phenomena responsible for this process. 
Based on the obtained determination coefficients $\left(R^{2}\right)$, it can be concluded that the adsorption rate of the investigated metal ions on MWCNT- $\mathrm{NH}_{2}$ at all experimental $\mathrm{pH}$ values is best described by $\mathrm{Ho}$ and McKay's pseudo-second order model. The suitability of this model is further confirmed by the fact that the experimentally obtained $q_{e}$ values are in good agreement with $q_{e}$ values theoretically determined by applying this model (Table 2). These results are consistent with the results of other authors which also indicate that the pseudo-second order model best describes the adsorption rate of divalent metal ions $(\mathrm{Pb}, \mathrm{Cu}$ and Cd) on oxidized CNT and MWCNT [9,35,25].

The pseudo-second order model assumes that the binding of adsorbate particles on the surface of a solid adsorbent occurs due to chemical binding [25]. In the case of the investigated adsorbent, chemical interactions can be achieved between the $-\mathrm{NH}_{2}$ groups on the surface of the MWCNTs and the selected heavy metal ions. Amino groups on the surface of the MWCNTs can engage free electrons in interacting with metal ions either through surface complexion (chemisorption), or by ion exchange, which usually take place simultaneously. Through chemisorption, metal ions tend to achieve the maximal coordination number. When adsorption takes place through chemisorption, it is assumed that the adsorption capacity is proportional to the number of occupied active sites on the surface of the adsorbent $[36,37,38,39]$. Based on all of the above, it can be concluded that the driving force governing the adsorption will be directly proportional to the number of available, potentially interacting adsorption sites on the surface of MWCNT-NH . To what extent these interactions will take place depends on several factors, including the chemical properties of both the adsorbent and the adsorbate which are, in turn, $\mathrm{pH}$ dependent.

Given that the characterization of the material determined that the investigated adsorbent MWCNT- $\mathrm{NH}_{2}$ represents a mesoporous material, it is assumed that the intra-particle diffusion of heavy metal ions can simultaneously take place during the adsorption process [25]. The Weber-Morris model was used to determine the contribution of intra-particle diffusion in the overall adsorption process. The graphical representations of the Weber-Morris kinetic model at selected $\mathrm{pH}$ values are presented in Figure 3, and the model parameters are given in Table 3.

Table 3. Parameters of the Weber-Morris kinetic models and determination coefficients for selected metals at different $\mathrm{pH}$ values

Tabela 3. Parametri kinetičkog modela Weber-Morriss i koeficijenti determinacije za odabrane metale na različitim $\mathrm{pH}$ vrednostima

\begin{tabular}{|c|c|c|c|c|c|c|c|}
\hline \multirow[b]{2}{*}{ Metal } & \multirow[b]{2}{*}{$\mathrm{pH}$} & \multicolumn{3}{|c|}{ External diffusion } & \multicolumn{3}{|c|}{ Intra-particle diffusion } \\
\hline & & $R^{2}$ & $\begin{array}{c}\boldsymbol{k}_{\boldsymbol{i}} \mathbf{1 0 ^ { - 3 }} \\
\left(\mathrm{mg} \mathrm{g}^{-1} \min ^{-0,5}\right)\end{array}$ & $C_{i}$ & $R^{2}$ & $\begin{array}{c}\boldsymbol{k}_{\boldsymbol{i}} 10^{-3} \\
\left(\mathrm{mg} \mathrm{g}^{-1} \min ^{-0,5}\right) \\
\end{array}$ & $C_{i}$ \\
\hline $\mathrm{Cu}$ & \multirow{3}{*}{3} & 0.966 & 13.6 & 0.62 & 0.729 & 7.13 & 1.99 \\
\hline $\mathbf{P b}$ & & 0.911 & 56.3 & 0.98 & 0.988 & 1.01 & 1.24 \\
\hline Cd & & 0.687 & 33.3 & 0.06 & 0.259 & 0.31 & 0.21 \\
\hline $\mathrm{Cu}$ & \multirow{3}{*}{4.5} & 0.879 & 104 & 0.33 & 0.929 & 9.13 & 1.08 \\
\hline $\mathbf{P b}$ & & 0.969 & 226 & 0.48 & 0.061 & 22.0 & 7.80 \\
\hline Cd & & 0.722 & 2.11 & 0.13 & 0.423 & 0.44 & 0.36 \\
\hline $\mathrm{Cu}$ & \multirow{3}{*}{6} & 0.892 & 196 & 0.31 & 0.151 & 1.15 & 1.24 \\
\hline $\mathrm{Pb}$ & & 0.940 & 63.1 & 1.07 & 0.852 & 5.12 & 1.93 \\
\hline Cd & & 0.855 & 220 & 0.33 & 0.483 & 32.3 & 1.60 \\
\hline $\mathrm{Cu}$ & \multirow{3}{*}{11} & * & * & * & * & * & * \\
\hline $\mathrm{Pb}$ & & 0.774 & 95.6 & 1.54 & 0.353 & 33.8 & 11.5 \\
\hline Cd & & * & * & * & * & * & * \\
\hline
\end{tabular}

* The values of these parameters are omitted, since the cause of the selected metals removal was not solely related to adsorption to MWCNT-NH , but also to other phenomena responsible for this process. 

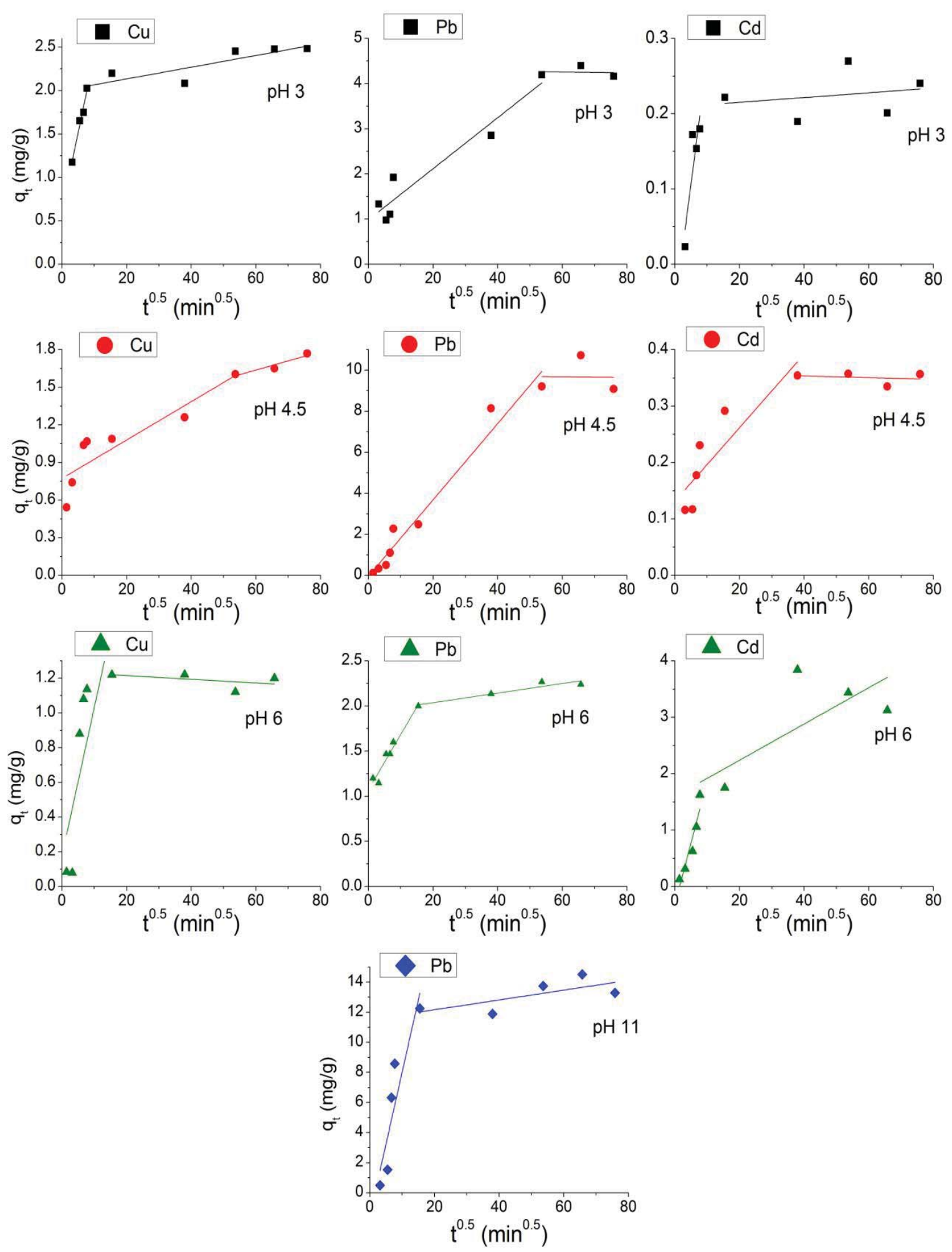

Figure 3. Weber-Morris model for selected metals at different $\mathrm{pH}$ values

Slika 3. Weber-Morriss-ov model za odabrane metale na različitim $\mathrm{pH}$ vrednostima 
Figure 2 shows two separate areas: the first area in the form of a steep part of the curve describes the diffusion of metal ions through the solution towards the outer surface of the nanomaterial (external diffusion), while the other, slower area is the gradual reaching of the adsorption-desorption equilibrium corresponding to diffusion of adsorbate within the pores of the adsorbent and the interstitial channels contained within the agglomerates of the MWCNT-NH particles (intra-particle diffusion) [25]. Based on the obtained results (Table 3 ), it can be concluded that the external diffusion is not a limiting step in terms of the adsorption rate of the selected metal ions on MWCNT- $\mathrm{NH}_{2}$, and that the intra-particle diffusion contributes in the removal mechanism. In order for intra-particle diffusion to be the only step limiting the adsorption process, the linear dependence of $q_{t}$ in the function $t^{0.5}$ must pass through the ordinate of the coordinate system. Since all cases examined in this paper gave an intercept on the ordinate axis, it can be concluded that the intra-particle diffusion is not the only mechanism limiting the overall adsorption rate. Similar results were obtained by Tofighy and Mohammadi [35] who investigated the adsorption rates of $\mathrm{Cu}$ (II), $\mathrm{Zn}$ (II), $\mathrm{Pb}$ (II), Cd (II) and Co (II) on oxidized CNTs at lower (100 mg/L) and higher initial concentrations (1200 mg/L) of heavy metals. These authors found that the adsorption of metal ions at lower initial concentrations took place in two steps indicating that the adsorption process was controlled by the chemisorption, external diffusion, and partially intra-particle diffusion, while the adsorption rate at higher initial concentrations indicated intra-particle diffusion as the primary adsorption process. Authors Salam et al. [25], who investigated the removal of $\mathrm{Cu}$ (II), $\mathrm{Pb}$ (II), Cd (II), and $\mathrm{Zn}$ (II) on MWCNTs modified with 8-hydroxyquinoline, concluded that the intercept $\left(C_{i}\right)$ different from zero, represents a sufficient proof that the intra-particle diffusion, although a very slow process, can not be regarded as a limiting step of the adsorption process of selected metals, and that the adsorption rate is governed by the interactions of these metals with the surface groups of the adsorbent.

\section{CONCLUSION}

This study investigated the adsorption behavior of three selected divalent metals (Cu (II), Cd (II), $\mathrm{Pb}$ (II)) on the amino-functionalized carbon nanomaterial, MWCNT-NH , at four $\mathrm{pH}$ values (3; 4.5; 6 and 11), in order to investigate the potential of using MWCNT-NH $\mathrm{N}_{2}$ for metal ions removal from aqueous solutions at relatively low concentrations (0.1-1 mg/L). The investigated nanomaterial has a specific surface area of $181.9 \mathrm{~m}^{2} / \mathrm{g}$ and a mean pore diameter of $14.64 \mathrm{~nm}$. Micropores were not detected by the applied t-test, while the total pore volume is $1.31 \mathrm{~cm}^{3} / \mathrm{g}$. The point of zero charge is 6.4 .

Investigation of the adsorption kinetics has shown that the adsorption process takes place in two phases. The initial faster period (about $4 \mathrm{~h}$ ), is followed by a slower period during which adsorption equilibrium is reached. Adsorption equilibrium was reached after $48 \mathrm{~h}$ at all experimental $\mathrm{pH}$ values. The estimation of the adsorption rate dependence on the solution $\mathrm{pH}$ showed that the $\mathrm{pH}$ of the solution, in the investigated range, has the greatest influence on the adsorption efficiency of $\mathrm{Cu}$ (II) and the least influence on Cd (II) removal. In all the investigated cases (all metals and all pH values), the adsorption rate was best described by the pseudo-second order reaction model, which indicates the formation of chemical interactions between metal ions and binding sites on the surface of the adsorbent. The application of the Weber-Morris model showed that adsorption occurs in two steps, by diffusion of metal ions through the solution towards the outer surface of the nanomaterial (external diffusion) and by diffusion of adsorbates through the pores and the interstitial channels in the adsorbent (intraparticle diffusion). The results indicated that the intra-particle diffusion, although slower than the external diffusion, is not the only limiting step in the adsorption process, and that the adsorption rate also depends on the interactions of the investigated metal ions with the binding sites on the surface of the adsorbent.

\section{Acknowledgment}

The research was funded by the Ministry of Education, Science and Technological Development of Republic of Serbia through projects III43005 and TR37004. The authors also owe thanks to Dr. Ákos Kukovecz and Dr. Zoltán Kónya from the University of Szeged, Hungary, who synthesized the adsorbent used in this paper within the activities of the IPA CBC HU-SRB project MATCROSS.

\section{REFERENCES}

[1] S.N.Sin, H.Chua, W.Lo, L.M.Ng (2001) Assessment of heavy metal cations in sediments of Shing Mun River, Hong Kong, Environ. Int., 26, 297-301.

[2] S.Islam, K.Ahmed, M.Raknuzzaman, H.A.Mamun, M.K.Islam (2015) Heavy metal pollution in surface water and sediment: A preliminary assessment of an urban river in a developing country, Ecol. Indic., 48, 282-291.

[3] K.M.Mohiuddin, K.Otomo, Y.Ogawa, N.Shikazono (2012) Seasonal and spatial distribution of trace elements in the water and sediments of the Tsurumi 
River in Japan, Environ. Monit. Assess., 184, 265279.

[4] J.Agbaba, B. Dalmacija, S.Maletić, S.Rončević, Lj.Božović (2008) Neorganske komponente u sistemu voda-sediment $\mathrm{U}$ : Zagađujuće materije u vodenom ekosistemu i remedijacioni procesi (Urednici: Dalmacija, B. i Agbaba, J.), Prirodnomatematički fakultet u Novom Sadu, Departman za hemiju, biohemiju i zaštitu životne sredine i Centar izvrsnosti za hemiju okoline i procenu rizika, Novi Sad.

[5] D.Tasis, N.Tagmatarchis, A.Bianco, M.Prato (2006) Chemistry of carbon nanotubes, Chem. Rev., 106, 1105-1136.

[6] S. Srivastava (2013) Sorption of divalent metal ions from aqueous solution by oxidized carbon nanotubes and nanocages: A review, Adv. Mat. Lett., 4(1), 2-8.

[7] N.Savage, M.S.Diallo (2005) Nanomaterials and water purification: Opportunities and challenges, J. Nanopart. Res., 7, 331-342.

[8] F.Fu, Q.Wang (2011) Removal of heavy metal ions from wastewaters: A review, J. Environ. Manage., 92, 407-418.

[9] V.K.Gupta, O.Moradi, I.Tyagi, S.Agarwal, H.Sadegh, R.S.Ghoshekandi, A.S.H.Makhlouf, M.Goodarzi, A. Garshasbi (2016) Study on the removal of heavy metal ions from industry waste by carbon nanotubes: effect of the surface modification: A review, Crit. Rev. Environ. Sci. Technol., 46(2), 93-118.

[10] X.M.Ren, D.D.Shao, G.X.Zhao, G.D.Sheng, J.Hu, S.T.Yang, X.K.Wang (2011) Plasma induced multiwalled carbon nanotube grafted with 2vinylpyridine for preconcentration of $\mathrm{Pb}(\mathrm{II})$ from aqueous solutions, Plasma Processes Polym., 8(7), 589-598.

[11] G.P.Rao, C.Lu, F.Su (2007) Sorption of divalent metal ions from aqueous solution by carbon nanotubes: a review, Sep. Purif. Technol., 58, 224231.

[12] X.Ren, C.Chena, M.Nagatsu, X.Wang (2011) Carbon nanotubes as adsorbents in environmental pollution management: a review, Chem. Eng. J., 170, 395-410.

[13] Y.H.Li, S.G.Wang, J.Q.Wei, X.F.Zhang, C.L.Xu, Z.K.Luan, D.H.Wu, B.Q.Wei (2002) Lead adsorption on carbon nanotubes, Chem. Phys. Lett., 357, 263266.

[14] S.Banerjee, T.Hemraj-Benny, S.S.Wong (2005) Covalent surface chemistry of singlewalled carbon nanotubes, Adv. Mater., 17, 17-29.

[15] M.T.Byrne, Y.K.Gunko (2010) Recent advances in research on carbon nanotube-polymer composites, Adv. Mater., 22, 1672-1688.

[16] C.Chen, X.Wang (2006) Adsorption of Ni(II) from aqueous solutions using oxidized multiwall carbon nanotubes, Ind. Eng. Chem. Res., 45, 9144-9149.

[17] P.A.S.S.Marques, M.F.Rosa, H.M.Pinheiro (2000) $\mathrm{pH}$ effects on the removal of $\mathrm{Cu}^{2+}, \mathrm{Cd}^{2+}$ and $\mathrm{Pb}^{2+}$ from aqueous solution by waste brewery waste, Bioprocess. Eng., 23, 135-141.

[18] A.Kukovecz, Z.Konya, N.Nagaraju, I.Willems, A.Tamási, A.Fonseca, J.B.Nagy, I.Kiricsi (2000) Catalytic synthesis of carbon nanotubes over $\mathrm{Co}$, $\mathrm{Fe}$ and Ni containing conventional and sol-gel silicaaluminas, Phys. Chem. Chem. Phys., 2, 3071-3076.

[19] L.Wang, S.Feng, J.Zhao, J.Zhenga, Z.Wanga, L.Li, Z.Zhua (2010) A facile method to modify carbon nanotubes with nitro/amino groups, Appl. Surf. Sci., 256, 6060-6064.

[20] J.S.Noh, J.A.Schwarz (1990) Effect of $\mathrm{HNO}_{3}$ treatment on the surface acidity of activated carbons, Carbon., 28, 675-682.

[21] Y.Tian, B.Gao, V.L.Morales, L.Wu, Y.Wang, R.M.Carpena, C.Cao, Q.Huang, L.Yang (2012) Methods of using carbon nanotubes as filter media to remove aqueous heavy metals, Chem. Eng. J., 210, 557-563.

[22] A.Šućurović, J.Tričković, S.Maletić, M.Kragulj Isakovski, A.Kukovecz, M.Prica, B.Dalmacija (2017) Effects of Anions on Adsorption of Trace Levels of $\mathrm{Cu}(\mathrm{II}), \mathrm{Pb}(\mathrm{II})$ and $\mathrm{Cr}(\mathrm{VI})$ by Amino-Functionalized Multi-Walled Carbon Nanotubes, Rev. Chim, 68(2), 362-368.

[23] USEPA Method 7000B (2007) Flame atomic absorption spectrophotometry, Revision 2.

[24] USEPA Method 7010 (2007) Graphite furnace atomic absorption spectrophotometry.

[25] M.A.Salam, G.Al-Zhrani, S.A.Kosa (2014) Removal of heavy metal ions from aqueous solution by multiwalled carbon nanotubes modified with 8hydroxquinoline: Kinetic study, J. Ind. Eng. Chem., 20, 572-580.

[26] Y.S.Ho (2006) Review of second-order models for adsorption systems, J. Hazard. Mater., 136(3), 681689.

[27] F.Wu, R.Tseng, R.Juang (2009) Characteristics of Elovich equation used for the analysis of adsorption kinetics in dye-chitosan systems, Chem. Eng. J., 150, 366-373.

[28] M.A.Atieh, O.Y.Bakather, B.Al-Tawbini, A.A.Bukhari, F.A.Abuilaiwi, M.B.Fettouhi (2010) Effect of Carboxylic Functional Group Functionalized on Carbon Nanotubes Surface on the Removal of Lead from Water, Bioinorg. Chem. Appl., 2010, 1-9,

[29] A.Stafiej, K.Pyrzynska (2007) Adsorption of heavy metal ions with carbon nanotubes, Sep. Purif. Technol., 58, 49-52.

[30] N.V.Perez-Aguilar, E.Muñoz-Sandoval, P.E.DiazFlores, J.R.Rangel-Mendez (2010) Adsorption of cadmium and lead onto oxidized nitrogen-doped multiwall carbon nanotubes in aqueous solution: equilibrium and kinetics, J. Nanopart. Res., 12(2), 467-480.

[31] C.Lu, C.Liu (2006) Removal of Nickel(II) from aqueous solution by carbon nanotubes, J. Chem. Technol. Biotechnol., 81, 1932-1940. 
[32] G.Vuković, A.D.Marinković, S.Škapin, M.Đ.Ristić, R.Aleksić, A.A.Perić-Grujić, P.S.Uskoković (2011) Removal of lead from water by amino modified multi-walled carbon nanotubes, Chem. Eng. J., 173, 855-865.

[33] A.Maleki, U.Hamesadeghi, H.Daraei, B.Hayati, F.Najafi, G.McKay, R.Rezaee (2017) Amine functionalized multi-walled carbon nanotubes: Single and binary systems for high capacity dye removal, Chem. Eng. J., 313, 826-835.

[34] Z.Zhao, Z.Yang, Y.Hu, J.Li, X.Fan (2013) Multiple functionalization of multi-walled carbon nanotubes with carboxyl and amino groups, Appl. Surf. Sci., 276, 476-481.

[35] M.A.Tofighy, T.Mohammadi (2011) Adsorption of divalent metal ions from water using carbon nanotube sheets, J. Hazard. Mater., 185, 140-147.
[36] Y.S.Ho, G.McKay (1999) Pseudo-second order model for adsorption processes, Process Biochem., 34, 451-465.

[37] W.Zou, R.Han, Z.Chen, Z.Jinghua, J.Shi (2006) Kinetic study of adsorption of $\mathrm{Cu}(\mathrm{II})$ and $\mathrm{Pb}$ (II) from aqueous solutions using manganese oxide zeolite in batch mode, Colloids Surf. A, 279, 238-246.

[38] S.Figaro, J.P.Avril, F.Brouers, A.Ouensanga, S.Gaspard (2009) Adsorption studies of molasses wastewaters on activated carbon: modeling with a new fractal kinetic equation and evaluation of kinetic models, J. Hazard. Mater., 161, 649-659.

[39] S.I.Lybchik, A.I.Lyubchik, O.L.Galushko, L.P.Tikhonova, J.Vital, I.M.Fonseca, S.B.Lyubchik (2004) Kinetics and thermodynamics of the $\mathrm{Cr}$ (III) adsorption on the activated carbon from commingled wastes, Colloids Surf. A, 242, 151-158.

\title{
IZVOD
}

\section{KINETIKA ADSORPCIJE DVOVALENTNIH METALA NA AMINOFUNKCIONALIZOVANOM UGLJENIČNOM NANOMATERIJALU}

\begin{abstract}
Predmet istraživanja ovog rada bio je ispitivanje adsorpcionog ponašanja odabranih dvovalentnih metala (Cu(II), Cd(II), Pb(II)) na amino-funkcionalizovanim višeslojnim ugljeničnim nanocevima, MWCNT-NH$H_{2}$, na četiri odabrane $\mathrm{pH}$ vrednosti (3; 4,5; 6 i 11), a u cilju ispitivanja mogućnosti primene MWCNT-NH$H_{2}$ za uklanjanje jona metala iz vodenih rastvora u oblasti relativno niskih koncentracija $\left(0,01-0,1 \mathrm{mg} \mathrm{L}^{-1}\right)$. Fokus rada je bio na utvrđivanju mehanizma procesa adsorpcije $u$ ispitivanim uslovima. Adsorpciju jona dvovalentnih metala na MWCNT-NH$H_{2}$ najbolje je opisao reakcioni model pseudo-drugog reda što znači da adsorpcija može biti pripisana uspostavljanju hemijskih interakcija između adsorbata i vezivnih grupa na površini adsorbenta. Modelovanje brzine Weber Morris-ovim difuzionim modelom ukazalo je na to da unutarčestična difuzija, iako sporiji korak od eksterne difuzije, nije jedini ograničavajući korak u procesu adsorpcije, već su za to odgovorne $i$ interakcije ispitivanih jona sa vezivnim mestima na površini adsorbenta. Procena uticaja $\mathrm{pH}$ vrednosti na brzinu procesa pokazala je da $\mathrm{pH}$ vrednost, $u$ ispitivanom opsegu, ima najveći uticaj na efikasnost adsorpcije Cu(II), a najmanji na uklanjanje Cd(II).
\end{abstract}

Ključne reči: nanomaterijali, dvovalentni metali, adsorpcija, kinetika.

Naučni rad

Rad primljen: 19. 02. 2018.

Rad prihvaćen: 25. 04. 2018.

Rad je dostupan na sajtu: www.idk.org.rs/casopis

(c) 2018 Authors. Published by Engineering Society for Corrosion. This article is an open access article distributed under the terms and conditions of the Creative Commons Attribution 4.0 International license (https://creativecommons.org/licenses/by/4.0/) 